\title{
Historians of American Communism
}

\section{John E. Haynes}

Silver Springs, Maryland

The Historians of American Communism developed out of a chance meeting of five scholars at the Upper Great Lakes History Conference in 1980. The scholars shared a mutual interest in one or another aspect of the history of American Communism and found that their exchanges were mutually beneficial. They decided that in view of the recent increase in scholarly interest in Communist history and the lack of knowledge of many researchers about the activities of others working in the same field, a loose association of those interested in the field made sense. These scholars (Lowell Dyson, John Haynes, Hyman Berman, Bill Pratt, and Harvey Klehr) constituted themselves as an informal organizing committee to form such an association.

The committee gathered names of scholars who might be interested in forming such a group, and Lowell Dyson sent letters inviting them to a meeting held in conjunction with the April 1982 convention of the Organization of American Historians. The discussion at the subsequent meeting indicated that there was interest in an organization which would allow scholars interested in some aspect of the history of American Communism to find out what research others were pursuing and which would facilitate exchange of information on sources or answering of research queries. The meeting also adopted the name Historians of American Communism and added Max Gordon to the organizing committee (entitled the General Organizing Board).

A second organizational meeting was held in conjunction with the December 1982 convention of the American Historical Association. At this meeting Hyman Berman reported on the status of research in American History in the People's Republic of China based upon his observations as a lecturer on American labor history at Nankai University in 1981. The meeting also discussed the draft constitution and bylaws prepared by the General Organizing Board. A revised constitution and bylaws and a set of officers were elected in a mail ballot in March, 1983. Hyman Berman, professor of history at the University of Minnesota, was elected as the organization's first president.

The Historians of American Communism publish a newsletter (edited by 
John Haynes) which appears quarterly. The Newsletter carries information about sources, research in progress, queries from researchers, and other items of professional interest. Membership is $\$ 5.00$ a year, including subscription to the Newsletter. The organization's address is Historians of American Communism, c/o Lowell K. Dyson, 820 King St., Suite 3, Alexandria, Va 22314. 